\title{
Innovation Management and Marketing in Global Enterprises
}

\author{
A. Nur $\operatorname{Ersun}^{1} \&$ A. Tuğba Karabulut ${ }^{1}$ \\ ${ }^{1}$ Faculty of Commercial Sciences, Istanbul Commerce University, Turkey \\ Correspondence: A. Tuğba Karabulut, Faculty of Commercial Sciences, Istanbul Commerce University, Istanbul, \\ Turkey. Tel: 90-4-440-413. E-mail:tkarabulut@ticaret.edu.tr
}

Received: July 9, 2013

Accepted: August 14, 2013

Online Published: September 22, 2013

doi:10.5539/ijbm.v8n20p76

URL: http://dx.doi.org/10.5539/ijbm.v8n20p76

\begin{abstract}
Nowadays, innovation has been more important for increasing competitiveness of global enterprises. Global enterprises need to redesign their management and marketing strategies and practices continously to improve and sustain their competitive positions. Innovation is considered as developing and managing new products and new markets. Innovation has been differentiated as products, processes, marketingand management practices. It targets value creation instead of reinventing. Marketing policies determine positioning, prices, distribution channels, and promotion for innovative products. The purpose of this paper is to make a brief review of the literature in the fields of innovation management and innovation marketing, and propose an "Integrated Model for Innovation Management and Marketing". It is expected that this study will shed some light to further studies in the field management and marketing coordination in companies.
\end{abstract}

Keywords: innovation management, innovation marketing, global enterprises, competitiveness

\section{Introduction}

Nowadays, innovation has been more important for increasing competitiveness of global enterprises. Top management of enterprises should consider competition globally. Innovation is indispensible in an extremely competitive business environment. Consumers have become more sophisticated and knowledgeable in searching innovation in all markets and countries. Global enterprises need to redesign their management and marketing strategies and practices continously to improve and sustain their competitive positions. The stages of product life cycle are getting shorter. Innovation is considered as developing new products and markets in this paper. It has been differentiated as products, processes, marketing and management practices. It targets value creation instead of reinventing. Enterprises which are innovation oriented, adopt innovation easily, and be innovative to have competitive advantages in their local and global markets.

Innovation ability has been considered as a main success factor for survival and performance of companies (Schumpeter, 1934; Burns \& Stalker, 1961; Porter, 1990) in various industries (Huff, 1990; Cooper and Kleinschmidt, 1991; Guan et al., 2009) (Sánchez et al., 2011). Igartua et al. (2010) state that innovation leads company to grow and have sustainable competitive advantage. Thus, innovation management is important for companies. Vaccaro et al. (2010) believe that innovation is the major strategic tool in global economy to enable companies improve their success by increasing their profits and revenues, and achieving more stakeholder and customer satisfaction.On the other hand, innovation includes improving processes for exploitingtechnologies, being more responsive to markets, getting advantages oftheir opportunities, and satisfying customers.More companies try to understand how they can innovate more and faster. Innovation's focus has shifted to value creation (Özgen \& Ölçer, 2007). Delighting customers is possible by undertaking innovation.

Value creation becomes more important for competition. Marketing function especially focus on it and try to lead innovation process and activities for value creation to satisfy customers and other stakeholders. Slater (1997) points out that the market orientation is a main resource for superior customer value creation. Woodruff (1997) and Zeithaml (1988) believe that customer value is a trade-off between perceived product quality and perceived price (Ingenbleek et al., 2010). Arrow (1962) has opened the gate to conduct studies about value of innovation for a company (Chen, 2006). Cooper \& Kleinschmidt $(1987,1993,2000)$ reveal that marketing activites have positive influences on new product's success. Gardener et al. (2000) believe that requirements lead companies to formulate different marketing strategies (Gerhard et al., 2011). Melnyk \& Dehtyarova (2012) explain that innovative marketing measures leadcompany survival under global competition. Innovative 
marketing's main objective is market advancement strategy development. Strategic marketing research analyses market, market segments, demand, and consumer behavior.

There are innovations in processes, products, and their marketing. Development of new marketing tools and methods is essential for industrial evolution. Newconsumer informationgathering methods by applying innovative marketing programs and technologies enable companies to reach customers more effectively and use new pricing strategies. Although marketing innovation is important, it has not received enough attention in the literature (Chen, 2006). Moreau et al. (2001) explain that when companies understand strategic and financial importance of new product launch, consumer's adoption process and its causes better, they can formulate more effective segmentation, positioning, and launching strategies (Vaccaro et al., 2010). Martin (2011) believe that companies become innovativedue to their customers. They conduct researches to estimate demands and expectations of their customers (Dumitrecu, 2011).

Innovative companies have innovator entrepreneurs or top managers to initiate and support innovative approaches for success and survival of companies. Examples of these innovative companies have been highlighted in the literature as follows. Lafley who is P\&G's former CEO states that makingqualitative judgment about consumer behavior researchleaded him success. Heplanned to produce compact detergent to decreasecosts of production, packaging, and transportation, and space needs of retailers and warehouses. Although, consumer surveys did not show enough demand for compact detergents, he conducted a qualitative research which showed most of the customers were indifferent about them. Thus, $P \& G$ launched compact detergents and became successful. Leaders of companies perform with uncertainty and calculated risk. Nowadays, there are faster technological changes and more innovations than ever. The largest companies have been managed by Momentum Leaders who know their customers, understand values they have to deliver, excel on 7P's of marketing namely product, price, promotion, placement, people, physical evidence and process to delight their customers. Sam Walton believed that large-scale retailing should be achieved differently. Steve Jobs understood that customers wanted to have emotional relationships with their gadgets. Richard Branson believes that air travelmay be enjoyable (Dumitrecu, 2011).

Definitions, dimensions, types and studies of innovation will be discussed in the next section. The concept of innovation management and related studies from the World will be discussed in the third section. Innovation management models and innovation marketing will be presented in the two respective sections. Integrated Model for Innovation Management and Marketing will be proposed by authors of this paper in the 6th section and conclusion will wrap-up the paper.

\section{Definitions, Dimensions, Types and Studies of Innovation}

Definitions and dimensions of innovation have been studied and analyzed by various researchers as indicated in Table 1 and Table 2 below.

Table 1. Definitions of Innovation

\begin{tabular}{ll}
\hline Researchers & Definitions of Innovation \\
\hline Dosi (1982) & A problem-solving process \\
Kline \& Rosenberg(1986) & An interactive process involving relationships amongcompaniesandvarious actors \\
$\begin{array}{l}\text { Cohen \& Levinthal(1990) } \\
\text { Dogson (1991) }\end{array}$ & $\begin{array}{l}\text { A diversified learning process. Learning may arise from learning-by-using, learning-by-doing, } \\
\text { learning-by-sharing internal or external sources of knowledge and absorption capacity of companies }\end{array}$ \\
Patel \& Pavitt (1994) & A process involving exchange of codified and tacit knowledge \\
Edquist (1997) & An interactive process of learning and exchange where interdependence between actors generates an \\
& innovative system or an innovation cluster \\
Narvekar \& Jain (2006) & The process of taking an original idea and converting it into measurable business value \\
Sánchez et al. (2011) & Set of activities which offer competitive advantages to a company \\
\hline
\end{tabular}

Resources: Hidalgo, A.,\&Albors, J. (2008).Innovation management techniques and tools: A review from theory and practice. $R \& D$ Management, 38(2), 113-127; Özgen, H.,\& Ölçer, F. (2007). An evaluative study of innovation management practices in turkish firms, International Journal of Business Research, 7(2), 53-63. 
Definitions of innovation includes learning, knowledge, value creation and competitive advantages which are quite popular concepts for business succcess in global markets.

On the other hand, there are several types of innovation in the literature. Some of them are as follows: Innovation studies classify radical and incremental innovation (Ohme, 2002; Hargadon, 2003). Strategic innovation, organizational innovation, technological innovation, business model innovation, process innovation, product innovation, and marketing innovation are systematic innovation types (Trott, 2005; Bate \& Johnson, 2005; Ohme, 2002). Hesselbein et al. (2002) add that disruptive and sustaining innovation are categorized by their effect on market and business have become popular (Özgen \& Ölçer, 2007). Kotler \& Caslione (2009) define disruptive innovation as a term which describes technological innovation, product or service which uses disruptive strategy instead of existing technologies or status quo products (Dumitrescu et al.,2011). Table 2 shows the dimensions of innovation.

Table 2. Dimensions of innovation

\begin{tabular}{|c|c|}
\hline Researchers & Dimensions of Innovation \\
\hline Schumpeter (1934) & Innovation as a driver for economic growth \\
\hline Porter (1980) & $\begin{array}{l}\text { Competitiveness of nations depend on ability of an industry to } \\
\text { innovate and improve innovations for achievement of } \\
\text { competitive advantage }\end{array}$ \\
\hline Oslo (2005) \& the Frascati Manual (2004) & A holistic view of innovation \\
\hline $\begin{array}{l}\text { Rogers (1983), Urabe (1988), Utterback (1994), Afuah (1998), Garcia } \\
\text { \&Calantone (2002), Mc Dermott \& O'Connor (2002), Pedersen \& } \\
\text { Dalum (2004) }\end{array}$ & $\begin{array}{l}\text { Finalconsumer of innovative goods or services, innovation } \\
\text { process }\end{array}$ \\
\hline Taylor, Drucker & $\begin{array}{l}\text { Innovation management involves theapplication of knowledge to } \\
\text { the work of knowledge workers }\end{array}$ \\
\hline Burns \& Stalker (1961) & $\begin{array}{l}\text { Organic and flexible structures that foster creativity by limiting } \\
\text { bureaucracy }\end{array}$ \\
\hline $\begin{array}{l}\text { Damanpour (1991), Henard \& Szymaski (2001), Grant (2005), Eunni } \\
\text { et al. (2005) }\end{array}$ & $\begin{array}{l}\text { One of the key strategic "processes" of companies is to adapt } \\
\text { both internally and externally }\end{array}$ \\
\hline $\begin{array}{l}\text { (Burns and Stalker, 1961; Parker, 1982; Kanter, 1983; } \\
\text { Leonard-Barton, 1992; Christensen, 1997). }\end{array}$ & $\begin{array}{l}\text { Importance of having mechanisms for systematic management of } \\
\text { innovation }\end{array}$ \\
\hline
\end{tabular}

Resources: Hidalgo, A.,\&Albors, J. (2008).Innovation management techniques and tools: A review from theory and practice. $R \& D$ Management, 38(2), 113-127;Sánchez, A., Alejandro L.,Ferràs, A. X., Ribera,J. (2011). Innovation management practices, strategic adaptation, and business results: Evidence from the electronics industry. Journal of Technology Management \&Innovation, 6(2), 14-39.

Dimension of innovation points out the importance of innovation process and innovation management which will be discussed in the next section. There are also several studies in the field of innovation.

As Hajikarimi et al. (2013) have mentioned several authors have studied in the field of innovation (Tornansky \& Fisher, 1990; Ulrich, 1995; Bleicher, 1999; Brandenberg, 2002; Sauber, 2003; Trot, 2005; Galanakis, 2006; Stamm, 2008; Birkinshaw, Hamel \& Mol, 2008). Adler et al. (1990) have realizedthe need organizational flexibility, process innovation, advanced manufacturing, capability, and product developmentto sustain technological innovation. Yam et al. (2004) believe thattechnological capabilities of companies and critical capabilities in strategic planning, organization, resource allocation, manufacturing, and marketing foster success of technological innovation (Sánchez et al., 2011).

On the other hand, Caudron (1999) has reminded a study conducted in 1998, 71\% of companies revealed "innovation" term exists in their mission statements, objectives and/or values. Coakes \& Smith (2007) have highlighted that innovation helps companiesto respond to market changes and remain competitive. They have developed a method to identify innovation champions in companies. Karlsberg \& Adler (2005) state that sustained innovation is caused by sense of purpose, unleashing employee creativity, and teaching them to recognize unconventional opportunities. Prajogo et al. (2007) have researched the importance of manufacturing strategies on innovation performance (Özgen \& Ölçer, 2007).

\section{The Concept of Innovation Management and The Related Studies from the World}

The concept of innovation management and related studies in the field of innovation management will be stated in this section. 
Innovation management is a process of economic implementation of ideas. The innovation implementation which promotes and initiates idea development and business opportunities is the organizational innovation system's design. Turrel \& Lindow (2003) highlight that innovation management's challenge is commercialization and institutionalization of ideas (Özgen \& Ölçer, 2007). Nowadays, innovation from lab to market is getting shorter.

Igartua et al. (2010) state that innovation management can be examined as follows: (1) innovation management is preconditions' creation to support creativity; (2) innovation management is a process to encourageknowledge application. They (2010) have examinedusage of innovation management techniques and tools in research unit of a leading Spanish elevator manufacturer to implement an open innovation strategy. They have explained the importance of innovation management tools to structure an open innovation strategy using technology transfer and collaboration.

Hidalgo \& Albors (2008) found out that a knowledge-driven economy influences the innovation process and approach in Europe. Nowadays, innovation'ssocial network theory where knowledge facilitates to foster innovation has been popular. Organizations initiate methodologies and tools to facilitate innovation management. Bin and Salles-Filhoa (2012) propose that technology development and innovation processes must be planned and managed. Sánchez et al. (2011) have developed a model to audit and classify innovation practices. This model also applies empirical analysis to determine effects of innovation practices on long term financial performance of companies. They found out that companies which have similar sizes, value chain positions, and ownership innovate similarly in the same regions. Using systematicinnovation approach increases revenues.

Hemmert (2008) has analysed innovation management of Japanese and Korean companies. He has found out that although both Japanese and Korean companies make high investments to develop new technologies and adopt advanced $R \& D$ management practices, fewer companies and industries focus on R\&D in Korea compared to Japan. On the other hand, Japanese companies are conservative and Korean companies are risk taking in their technology strategies. Korean companies prefer external technology from abroad more compared to Japanese companies. Both Korea and Japan have competitive advantages through product and process innovations in global competition.

There is a study from Turkey in the literature as well. Özgen \& Ölçer (2007) have investigated the innovation management practices of large Turkish manufacturing companies. They have found out that the 500 largest Turkish manufacturing companies focused on product and technology innovation, and applied incremental innovation projects instead of marketing and management innovation. They have added that the most important innovation obstacles are individual practices, resource insufficiencies, and innovation process management problems.

Studies in the field of Innovation Management shows that companies can survive and remain competititive if they succeed in innovation management. Innovation Management Models will be shown in the next section.

\section{Innovation Management Models}

There are several innovation management models in the literature. They have inspired the authors of this paper. However, there are limited innovation marketing models in the literature. The authors of this paper have integrated management innovation with marketing innovation to design a comprehensive innovation management and marketing model which can be considered as a leading integrated model. Some of the innovation management models are as follows:

Sarkar (2005) presents an integrated innovation model which describes a framework to understandcompany and market factors. Turrel and Lindow (2003) have developed "The Innovation Pipeline" which shows application of innovation methods and processes to achieve organizational goals. Birkinshaw \& Fey (2000) have worked on $\mathrm{R} \& \mathrm{D}$ resource allocation systems design and external technology sources usage to organize innovation.Chanal (2004) explains theoretical and managerial approaches to design innovative companies. Abbott (2005) states that innovative companies formorganizational climate providing visibility, transparency, and support to motivate their employees to upgrade the status quo (Özgen \& Ölçer, 2007).

Innovation management practices may be classifiedas follows: Management systems (Burns \& Stalker, 1961; Kanter, 1983; Leonard-Barton, 1992), creativity (Miltenburg, 1995), innovation strategy (Cooper and Kleinschmidt, 1995; Goffin and Pfeiffer, 2004), innovation culture (Chiesa et al., 1996; Burgelman et al., 2004), product and process innovation (Blindenbach-Driessen \& Ende, 2006), commercial innovation (Yam et al., 2004), technological innovation (Hamel \& Prahalad, 1994), and project management (Coombs \& Hull, 1998) (Sánchez, et al., 2011). 
Hajikarimi, et al. (2013) pointed out Xu et al.'s $(2002,2006$, 2007) Total Innovation Management's theoretical framework based on tri-totality in innovation. They believe that innovation should be conducted both in technological and non-technological elements such as strategy, culture, organization, and market. All employees should be involved to innovation process which should continue at all time and in all spaces.

Table 3 will present popular innovation management models in the literature which has inspired authors to develop their Integrated Model for Innovation Management and Marketing.

Table 3. Innovation management models

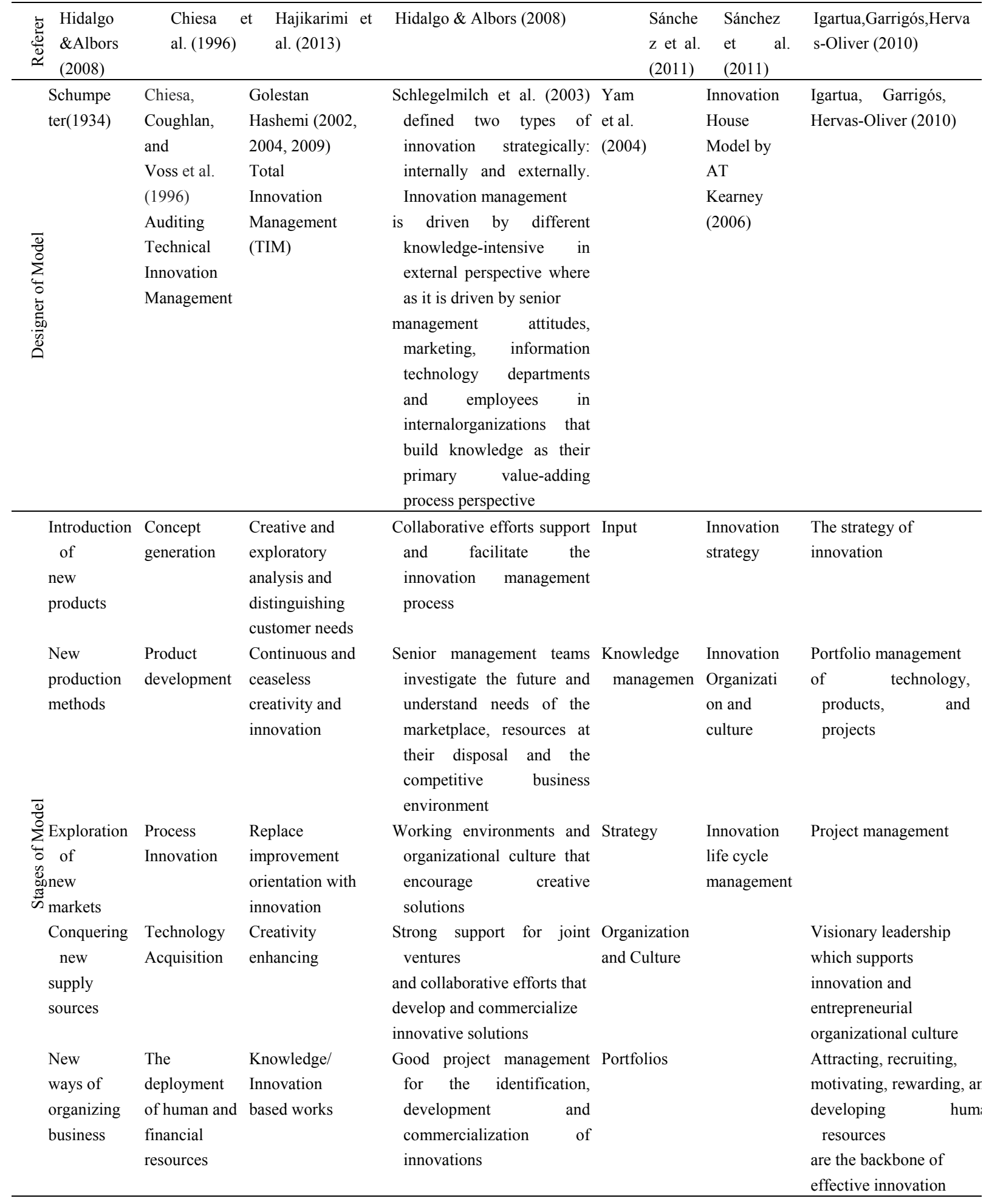




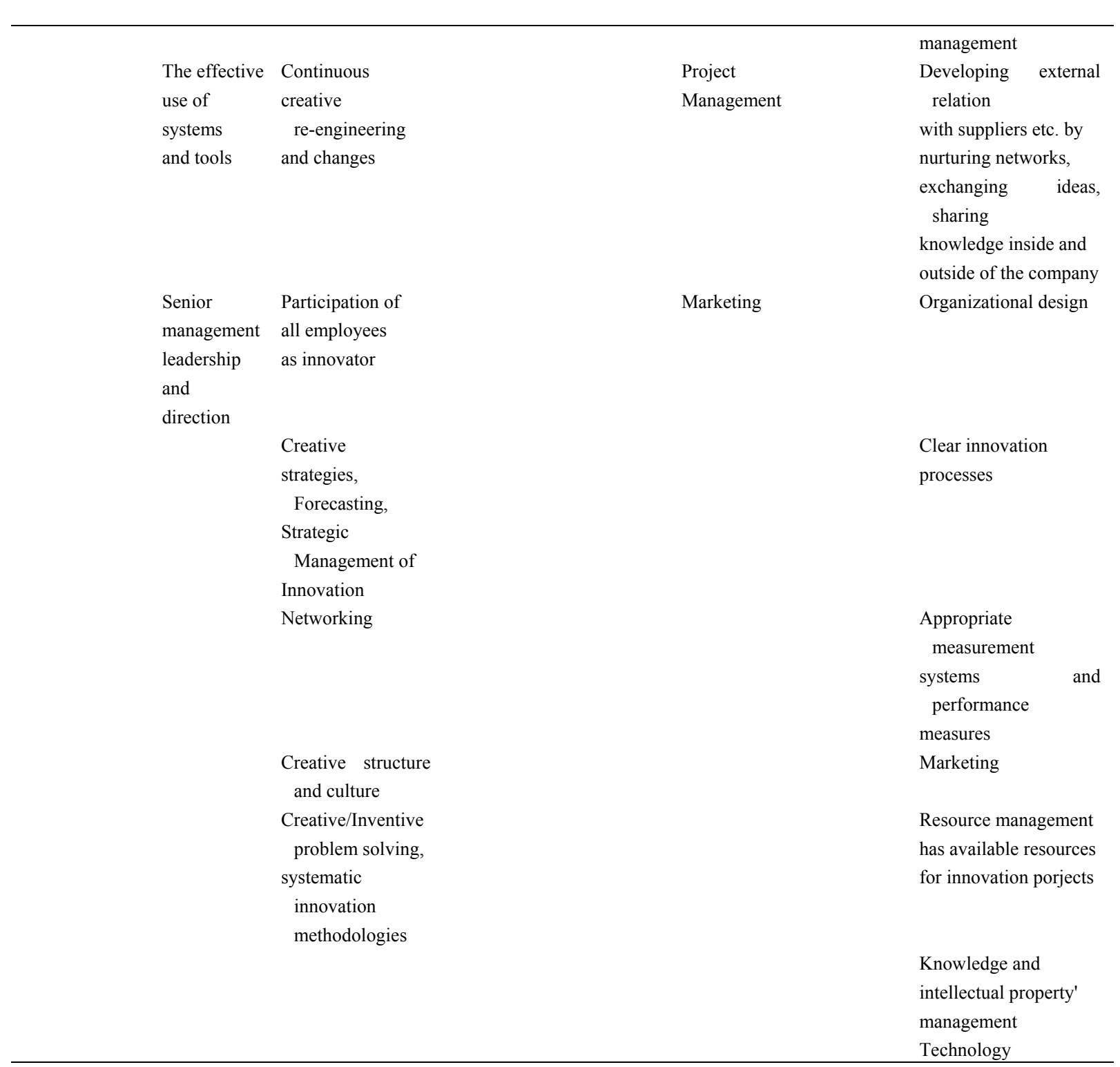

\section{Innovation Marketing}

Nowadays, competition is becomig thougher and global. Companies try to understand, gain and retain their customers by conducting researches. They need to meet and exceed needs and demands of their customers to satisfy and keep them for a long time. They aim to sell products and services continuously to their customers. They try to keep track of their customers. They try to gain family members and friends of their customers. Stages of product life cycleand time for an innovation from lab to market become shorter. Products of companies are imitated by their competitors when they are launched or before they are launched. Thus, marketing function has an essential role for companies' success and survival in the long term. The purpose of marketing function is to satisfy customers by determining, fulfilling and exceeding their needs. Companies need to innovate new products and services continously to achieve sustainable profitability. The 4P's of marketing have been extended to the 7Ps. All functions of marketing should be coordinated whereas marketing function should be integrated to other business functions. Marketing policies need to be integrated to business strategies to have long term approach to innovation and improve success of new products. Marketing of new technologies has become more important in global markets for sustainable competitive advantages. The purpose of this section is to highlight the importance of innovation marketing and discuss models in this field.

Drucker has indicated that marketing and innovation are linked. Marketing is related to company's growth and high performance whereas innovation is related to developing new products, technologies, strategies and business models for competitive advantages. Innovation which is critical to attract and retain customers helps 
companies to be market leaders. More values can be created for company's stakeholders via customer-driven innovation. Feeling connected to a product or service makes customers more loyal to the company. On the other hand, Goldman (2010) believes that change implies creativity. As an example, Microsoft which has failed to deliver modern technology products and services and fallen behind in web browsing market. Accenture survey reveals that $89 \%$ of top managers have agreed that innovation and cost management are essential for high performance. Although many companies invest more in innovation, few of them are serious to manage its process. New ideas can offer several benefits to innovative companies. Larreche has searched marketing investments' influence on the long-term growth of the world's largest 1000 companies. Therefore, Plodders, Pushers, and Pioneers have been emerged (Dumitrescu et al., 2011).

Marketing innovation is substantial for a company's success. Companies devote high budgets to innovation and try to achieve coordination among $\mathrm{R} \& \mathrm{D}$, production and marketingfunctions to innovate better products and services to beat their competitors. Phong-Inwong and Ussahawanitchakit (2011) show that marketing innovation affects marketing leadership. Naidoo (2010) believes that marketing innovation iscompany's ability to develop product differentiation anduse technology asa competitive advantage source. Shergill \& Nargundkar (2005) add that innovation enables distribution channels to connect with customers through internet and promotion. Marketing innovation is adopting product, choosing promotion, managing distribution chains. According to Charpavang \& Ussahawanitchakit (2010), marketing innovation is an activity to increase sales and profits. Companies use marketing innovation as a tool to have competitive advantages to analyze opportunities, market, and distribution channels (Phong-Inwong \& Ussahawanitchakit, 2011). Chen (2006) points out that marketing innovation is a stage of business method innovation.

Creativity initiates marketing innovation strategy which needs to be integrated to company strategies for coordination among functions. Many companies lead their employees to intrapreneurship to be more creative, find new ideas, form cross-functional teams, and use resources to convert these ideas into projects to develop new products and services. Gong et al. (2009) believe that goal setting theory affects marketing success whereas creativity theory explains new idea or new project development. Teece (2007) states that marketing innovation is a strategy to improve marketing success. Marketing strategy influences marketing innovation positively. Marketing innovation increases company's capability to create competitive global new projects. Hausman and Stock (2003) points out that creativity is substantial for achievement. Longterm organizational vision is the framework to initiate projects, products, and customer satisfaction. Dayan \& Benedetto (2010) adds that adopting customer change is dependent of know-how and teamwork. According to Chang et al. (2010) and Gong et al. (2009), creativity is a technique to achieve organizational objectives by creating new products. Teng et al., (1996) highlight that marketing strategy affects marketing innovation positively. Nguyen and Shanks (2009), Dewett \& Gruys (2007) believe that teamwork is fundamental to generate know-how, new ideas, innovation, andquality product. Spacapan \& Bastic (2007), Branzei \& Vertinsky (2006), Simpson et al. (2006) have concluded that marketing innovation in a form of product innovation, quality service, and technology for new product creation is company's ability for effective marketing. Thus, companies can sustain their competitive advantages (Phong-Inwong and Ussahawanitchakit, 2011).Many companies get the advantage of teamwork for being more innovative. Teams have synergic benefits and team members can complement each other to design unique and competitive products and services. Business Week (2006) has written that companies explore strategies to improve their performances through innovation and creativeness. They coordinate innovation by forming cross-functional teams. BMW applies this practice to design cars. The project team members from different departments work in the company's Research and Innovation Center for a certain time. Proximity speeds up car development and communication (Dumitrescu et al., 2011).

Stakeholders are important groups to be satisfied with company performance. Innovative companies need to integrate innovation with the 4P's of marketingand provide new ideas in their implementation to succeed in innovation marketing. Mast et al. (2005) underline that innovation marketing addresses external stakeholders of the company. The innovation communication strategy which is comprised of internal innovation communications, innovation marketing and innovation public relations need to be integrated to company communication strategy. Mohr (2001) adds that high-technology marketing comprises the 4 P's of marketing adjusted to high-technology products (Gerhard et al., 2011). Gerhard et al. (2011) believe that advertising is a way to communicate product technology related customer information.Innovative marketing include R\&D implementation, engineering, unlicensed invention trading, invention patents and their licensing, technological knowledge transfer, know-how transfer, technical documentation transfer, information exchange in meeting, joint production and venture organization (Melnyk \& Dehtyarova, 2012). Companies focuson advertising. When they develop innovative products, they need to explain their usages and benefits appropriately to their customers. 
Moreau (2001) believes the importance of functionalities to acquire new customers for new products. When customers understandabout functionalities about the new product message, switching costs become less important. Singh \& Schoenbachler (2001) have found that information about availability, quality, and components are used in advertising of technology products in several countries (Gerhard et al., 2011).

Mistakes made in pricing can decrease a product innovation's profitability. Companies can determine new product prices based on their perceived benefits and how they are traded against price by customers in value-informed pricing. Customer oriented companies use value informed pricing to offer great benefits in an advantageous product for their customers. Market performance is affected positively by value-informed pricing and relative product advantage. The strongest relationship occurs between market orientation and new product performance when companies integrate value-informed pricing in new product development proces. A market-oriented company examinesperceived customer value which makes a trade-off between price and benefits. Langerak and Robben, (1997) and Langerak et al. (2004) view pricing as a decision that will be made during the product launch. Ingenbleek et al. (2010) show that a customer orientation which needs coordination for new product development process is the main resource for value-informed pricing. Customer orientation is the first stage of a market-oriented culture. On the other hand, value-informed pricing affects market performance directly by generating behaviors to make pricing decisions to understand value perceptions and purchase intentions of customers. It improves performance through increased product advantage. Product innovation literature on market orientation has considered relative product advantage as a mediator between market orientation and product performance (Atuahene-Gima, 1996) (Ingenbleek et al. 2010).

Figure 1 shows marketing stages for an innovation project which inspired the authors of this paper to develop their model.

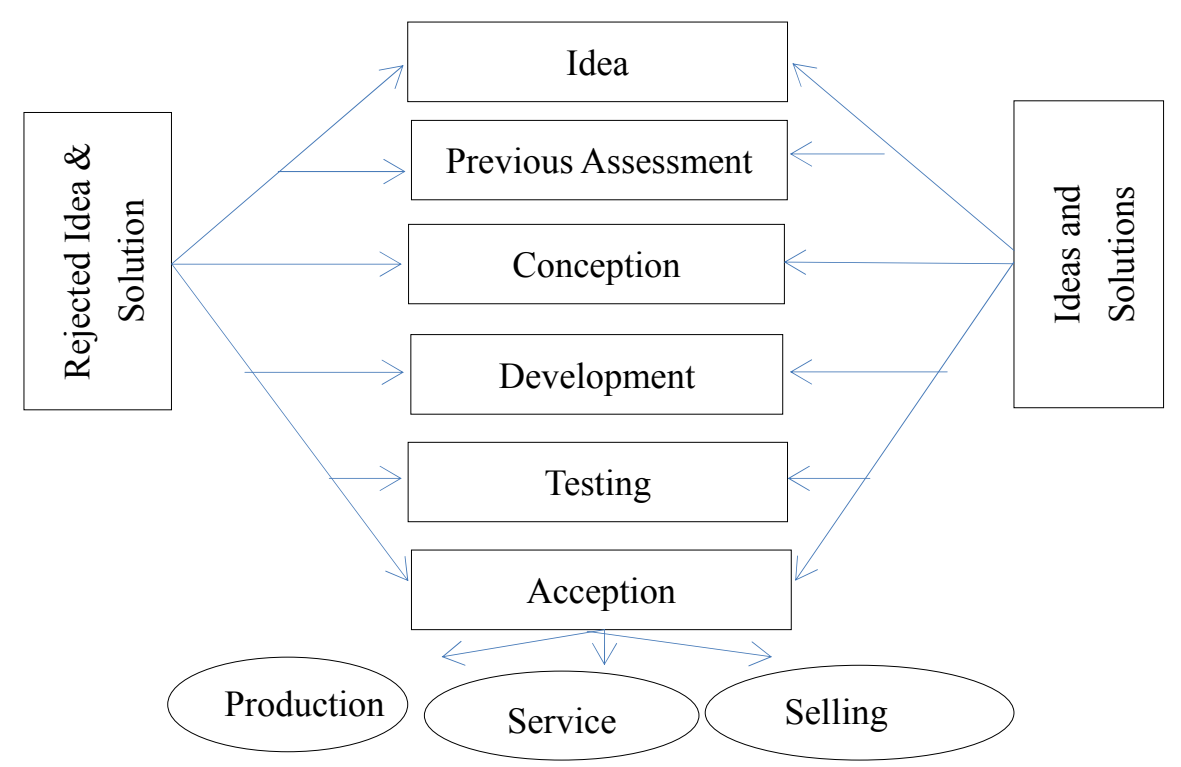

Figure 1. Marketing for an innovation project

Resource: Melnyk, L., \& Dehtyarova, I. (2012). Synergetic basis of innovation marketing. Economics and Business, 22, 121.

Strategic and operative components are essential types of innovative marketing as it is shown in Figure 1. Strategic innovative marketing is determined by market segmentation and positioning. Research and prognostication of demand for new products based on a consumer perception of innovation study is the key stage of marketing strategy. Market research whichis the main stage of innovative strategy to analyze external environment can explore macroeconomic factors related to innovation demand. It focuses on legal factors such as legislation practices of imports and exports for competitor products, quotas, limitations, taxes etc. Companies need to analyze national production of competitorproducts, import possibility, export level, production of national goods and innovation (Melnyk \& Dehtyarova, 2012).

Researches related to innovation diffusion presenthigh-tech products and services'adoption. According to Vaccaro (2008), there is a strong relationship between innovation characteristics' diffusion and marketing mix 
in a low-tech service sector. Moreau et al. (2001) explained that more effective segmentation, positioning, and launching strategies are possible when consumer's adoption process and its causes are understood better with a strategic approach to new product launch (Vaccaro et al., 2010).

Table 3. Diffusion characteristics, marketing strategies, global consumer values, internet lifestyles and perceived risk

\begin{tabular}{|c|c|c|}
\hline $\begin{array}{c}\text { Diffusion } \\
\text { Characteristics }\end{array}$ & $\begin{array}{l}\text { Marketing } \\
\text { Strategies }\end{array}$ & Global Consumer Values, Internet Lifestyles \& Perceived Risk \\
\hline Relative Advantage & Product Design & $\begin{array}{l}\text { Global Consumer Values: Efficiency of Technology/Progress } \\
\text { Internet Lifestyles: Expert, Competitive }\end{array}$ \\
\hline Complexity & $\begin{array}{l}\text { Cool Factor\& } \\
\text { Ease of Use }\end{array}$ & Perceived Risk: Safety, Convenience, Performance, Time/Effort \\
\hline Observabality & $\begin{array}{l}\text { Promotion } \\
\text { Cool Factor } \\
\text { (Brand Image) } \\
\text { and Functionality }\end{array}$ & $\begin{array}{l}\text { Global Consumer Values: Internet Community } \\
\text { Internet Lifestyles: Doer } \\
\text { Perceived Risk: Social, Psychological }\end{array}$ \\
\hline Compatibility & $\begin{array}{l}\text { Product, } \\
\text { Product applications }\end{array}$ & $\begin{array}{l}\text { Global Consumer Values: Consumer Rights/Freedom of Choice, Hedonism, } \\
\text { Aesthetics } \\
\text { Internet Lifestyles: Games, Hobbies \& Art, Change, Exploration/Discovery } \\
\text { Perceived Risk: Social, Psychological }\end{array}$ \\
\hline Triabilility & $\begin{array}{l}\text { Distribution, } \\
\text { Price }\end{array}$ & $\begin{array}{l}\text { Global Consumer Values: Consumer Rights/Freedom of Choice, Humanitarianism, } \\
\text { Ethics } \\
\text { Internet Lifestyles: Change, Exploration/Discovery } \\
\text { Perceived Risk: Financial, Time/Effort, Social, Psychological }\end{array}$ \\
\hline
\end{tabular}

Resource: Vaccaro, V. L., Ahlawat, S., \& Cohn, D. Y. (2010). Diffusion of innovation, marketing strategies, and global consumer values for a high technology product. International journal of business strategy, 10(3), 128.

Rogers (1983) has explained that diffusion of innovation theory study reveals the following products/services diffusion characteristics: 1) relative advantage, 2) observability, 3) compatibility, 4) complexity, and 5) trialabilityaffect adoption rate. Rogers' (1983) diffusion of innovation characteristics have been extended to include costs, uncertainty, social relevance and marketing program design. New products will be adopted faster when there is a bigger relative advantage, higher observability, more compatibility, less complexity, and bigger trialability. Vaccaro and Cohn (2007) haverevealedrelationshipsamong diffusion characteristics (Rogers, 1983), global consumer values (Williams, 1963), consumer internet lifestyle themes (Swinyard \& Smith, 2003), and perceived risk (Huff, 2000) for a high-tech consumer service. The study showsthat diffusion characteristics can be related to specific marketing strategies and competitive advantage benefits for high-tech products (Vaccaro et al., 2010). Diffusion is important for innvovation marketing. Innovation marketing plays a substantial role in company performance in relation to innovative strategies. Companies need to integrate their marketing and management functions to have a comprehensive approach to the implentation of their innovative strategies.

\section{Integrated Model for Innovation Management and Marketing}

An integrated model is proposed to highlight the importance of coordination between Innovation Management and Marketing. Both of these functions need to complement each other to gain and sustain competitive advantages both in local and global markets and reach high company performance. There are innovation management and marketing models in the literature. However, an interdisciplinary study which integrates these two approaches are not found. Thus, authors of this paper have decided to combine essential stages of innovation management and marketing to develop a unique and a leading comprehensive model for innovation management and marketing. Innovation management and marketing require team work of employees who have interdisciplinary overview and approach to innovation. This model provides synergic benefits of coordinating management and marketingto senior managers to gain innovative mind set and facilitate innovative culture in their companies. 


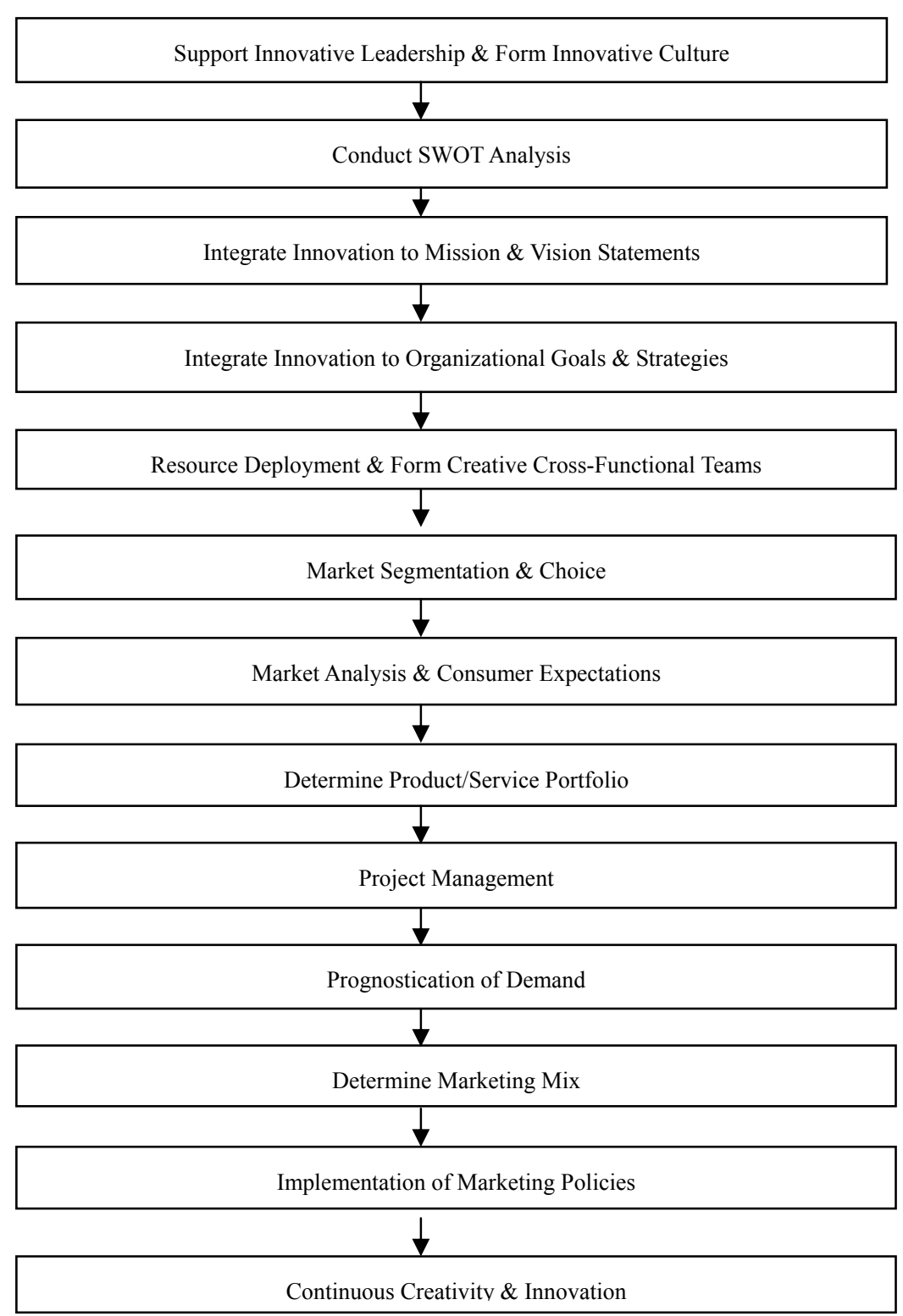

Figure 2. Proposed integrated model for innovation management and marketing

In Figure 2, an Integrated Model for Innovation Management and Marketing is being proposed. The importance of this model is its emphasise on leadership orientation and formation of innovative culture. This style of management serves as a trigger at the initial stage of innovative strategy. SWOT analysis is the most comprehensive essential in setting organizational mission and vision statements, organizational goals, and strategies. The next stage is resource deployment and formation of creative teams to start market segmentation. In the next state of innovative strategy, market research takes over to study the external environment of the organization. An innovative company needs to determine its product/service portfolio to conduct an appropriate project management process. Thus, prognastication of demand serves as a base to determine the marketing mix elements. Marketing policies should be implemented for sustainable creativity and innovation.

\section{Conclusion}

This paper has made a brief review of literature on innovation management and marketing. Although there are several studies in these fields, a model integrating innovation management and marketing has not been found. Thus, this finding has leaded authors to design a leading and a unique "Integrated Model for Innovation Management and Marketing" to highlight the importance of the coordination of management and marketing strategies in companies.Implementation of marketing instruments with the appropriate management strategies can allow increasing innovation efficiency and company performance. It is planned to conduct an empirical 
analysis on the 500 Largest Turkish Industrial Enterprises to support the importance of this model. It is expected that this study will shed some light to further studies in the field management and marketing coordination in companies.

\section{References}

Bin, A., \& Salles-Filhoa, S. (2012). Science, technology and innovation management: Contributions to a methodological framework. Journal of Technology Management \& Innovation, 7(2), 73-85. http://dx.doi.org/10.4067/S0718-27242012000200007

Chen, Y. (2006). Marketing innovation. Journal of Economics \& Management Strategy, 15(1), 101-123. http://dx.doi.org/10.1111/j.1530-9134.2006.00093.x

Chiesa, V., Coughlan, P., \& Voss, C. A. (1996). Development of a technical innovation audit. Journal of Product Innovation Management, 13(2), 105-136. http://dx.doi.org/10.1016/0737-6782(95)00109-3

Dumitrescu, L., Stanciu, O., Tichindelean, M., \& Vinerean, S. (2011). Pursuing a customer-driven approach for innovation and marketing excellence. Studies in Business and Economics, 16(2), 19-26.

Gerhard, D., Brem, A., Baccarella, C., \& Voigt, K. I. (2011). Innovation management and marketing in the high-tech sector: a content analysis of advertisements. International Journal of Management, 28(1), 330-348.

Hajikarimi, A., Hamidizadeh, M. R., Jazani, N.,Golestan, H., \&Sayed, M. (2013). A comprehensive systemic model of innovation management: Total innovation management (TIM). Interdisciplinary Journal of Contemporary Research in Business, 4(9), 1078-1088.

Hemmert, M. (2008). Innovation management of japanese and korean firms: A comparative analysis. Asia Pacific Business Review, 14(3), 293-314. http://dx.doi.org/10.1080/13602380802116757

Hidalgo, A., \& Albors, J. (2008). Innovation management techniques and tools: A review from theory and practice. $R \& D$ Management, 38(2), 113-127. http://dx.doi.org/10.1111/j.1467-9310.2008.00503.x

Igartua, J. I., Garrigós, J. A., \& Hervas-Oliver, J. L. (2010). How innovation management techniques support an open innovation strategy. Research Technology Management, 53(3), 41-52.

Ingenbleek, P. T. M., Frambach, R. T., \& Verhallen, T. M. M. (2010). The role of value-informed pricing in market-oriented product innovation management. Journal of Product Innovation Management, 27(7), 1032-1046. http://dx.doi.org/10.1111/j.1540-5885.2010.00769.x

Melnyk, L., \& Dehtyarova, I. (2012). Synergetic basis of innovation marketing. Economics and Business, 22, $118-123$.

Özgen, H., \& Ölçer, F. (2007). An evaluative study of innovation management practices in turkish firms. International Journal of Business Research, 7(2), 53-63.

Phong-Inwong, P., \& Ussahawanitchakit, P. (2011). Creativity, marketing innovation and marketing success: Evidence from home decoration export business in thailand. International Journal of Business Research, 11(4), 89-103.

Sánchez, A., Alejandro, L., Ferràs, A. X., \& Ribera, J. (2011). Innovation management practices, strategic adaptation, and business results: Evidence from the electronics industry. Journal of Technology Management \& Innovation, 6(2), 14-39.

Vaccaro, V. L., Ahlawat, S., \& Cohn, D. Y. (2010). Diffusion of innovation, marketing strategies, and global consumer values for a high technology product. International Journal of Business Strategy, 10(3), $113-128$.

\section{Copyrights}

Copyright for this article is retained by the author(s), with first publication rights granted to the journal.

This is an open-access article distributed under the terms and conditions of the Creative Commons Attribution license (http://creativecommons.org/licenses/by/3.0/). 